\title{
Mini-companies as an essential part of a lifelong learning program for high school students
}

\author{
Aleksandra Stevanović, Snježana Djurdjević, Bojana Sokolović
}

\section{Background and purpose of the research}

Education process today is an integral part of the era of turbulent exchanges, 4.0 industry, digitalization, and soft management. It requires an expanded definition of learning practicies where the significance of the relationship between schools and organizations becomes more prominent. In the literature, there is an attitude that business schools should respond with 'continuous attention' to theory/practice linkages (Porter, McKibbin, 1988). Systematic attention needs to be paid to the various types of company-based field experiences, their different learning objectives and expectations, the roles of all stakeholders in the learning process (Limerick, Moore, 1991). Authors pointed out on two clearly separated learning arenas: university and company. The university provides cognitive, intellectual framework; company or enterprise teaches skills in applying these to practice (ibid.). Everything aforementioned leads us to define 'student enterprises' which are presented by: extracurricular program of Junior Achievement Worldwide and Junior Achievement Europe.

In a junior achievements program, groups of high school students are organized into companies that 'sell' stock to raise capital, appoint employees, buy materials, manufacture and market a product, pay dividends to stockholders, and liquidate their company in the course of fifteen weeks. To manage their operations, students comprising each company make their own decisions regarding the appropriate amounts required for their own 
salaries, wages, and commissions. They must also keep production and financial records, pay rent for space and equipment, and pay taxes and dividends if profits are realized (Cousins R. et.al., 1995). Enterprise education is the application of creative ideas and innovations to practical situations with the aim to produce individuals with the mindset and skills of responding to opportunities, needs and shortfalls, the key skills including taking the initiative, decision making, problem solving, networking, identifying opportunities and personal effectiveness. Entrepreneurial frame can be applied to all areas of education, extending beyond knowledge acquisition to a wide range of emotional, social, and practical skills; and Entrepreneurship education is the application of enterprise skills specifically to the creation and growth of organizations, with entrepreneurship education focusing on developing skills and applying an enterprising mindset to the specific contexts of setting up a new venture, developing and growing an existing business, or designing an entrepreneurial organization (QAA, 2010).

Further,'student's enterprises', represents the world's largest enterpreneurship education program, which is attended by more than 10 million students a year. In Serbia, the program was implemented in 2006. Since then, over 60,000 students in 286 primary and secondary schools from all over the country have gone through educational programs in the field of enterpreneurship and financial literacy (Kisic, Petkovic, 2019). That way, students have the opportunity to learn through theoretical and practical lessons, a mentorship program, as well as through a number of fairs and competitions. During one academic year, students get an opportunity to create and manage their own enterprise with real issues and challenges. It seems to be their first practical enterpreneurship experience, so they get the opportunity to gain valuable knowledge and skills, and complement their theoretical knowlegde with basic skills of managing a business. In the paper we emphasise the significance of interactive learning projects involving students and their teachers, who are at the same time mentors and additional support of student organizations. In the research we aim to elaborate the influence of Junior Achievement programs (student-organizations) in Serbia, on the students' increasing knowledge and skills. We examined the possibility of students' skill development and knowldege expansion, and how these different aspects of practical learning lead students to increase competences for doing business. The development of those skills is guidance for their future business and management capabilities, and their competitiveness at the labor market. The key point of this program is to teach 
students how to be proactive and enterpreneurship-oriented, as well as to encourage them to think in an innovative and responsible way. European and worlwide researches refer to the impact of 'student-enterprises' on the significant improvement and development of skills: presentation skills, collaboration and team spirit, risk management, problem-solving abilities, adaptability, self-confidence, negotiation skills, ability to persuade, creative thinking, time management, etc. The ultimate goal of this study is to verify whether there is important influence of 'student-enterprises on the attitude of an individual ability for promoting skills, knowledge, and competences toward enterpreneurial spirit.

\section{Positive effects of different enterpreneurship programmes on student's knowlegde}

Results obtained in the study of ICEE (The Innovation Cluster for Entrepreneurship Education) indicate the following teacher's attitudes: Teachers believe that program offers clear and significant results in the development of:

1. Students' attitudes (creativity, achievement tendency, persistence, risk taking etc.)

2. Skills (setting goals, team work, communication skills, presentation skills)

3. Meaningful knowledge related to different phases in the business (ideas, business plan, production, presentation etc.)

4. Personal development of students (self-confidence, competence, responsibility, commitment, proactivity, independence) (Kisic, 2019).

Authors (Wiliamson N. et.al., 2013) presented outcomes and impacts of entrepreneurship education studying the literature and indicated that:

1. Participation does lead to students acquiring relevant business-related knowledge, skills and competences for enterprise and entrepreneurship;

2. Participants are more likely to change attitudes, such as those concerning risk taking, and intentions, such as attitudes concerning self-employed or being entrepreneurial, than non-participants; 
3. Studies show mixed results about whether such courses increase students' perception of feasibility; it is greater in Wales where enterprise and entrepreneurship education appears to be more embedded in school and FE (Further education) than in England;

4. There is no evidence that students are more likely to take steps as a result of courses towards the development stage of a new business or using the skills gained to develop new business opportunities in an existing small or large business;

5. There are, however, positive statistical relationships between various enterprise and entrepreneurship education learning activities in school and tertiary education and economic impacts including starting a new business (strong evidence for entrepreneurship course graduates); increasing employability and earnings; and contributing to the growth of businesses (especially for graduates entering small businesses). These suggest that enterprise and entrepreneurship education is a positive stimulus;

6. One study suggests a net positive impact on GVA (Gross value added) of enterprise and entrepreneurship education in $\mathrm{HE}$ (Higher education).

\section{Methodology}

An examination sample size was 269 respondents. It included 174 students employed in student companies, and 95 teachers hired as a menthors in student's companies founded by high schools of Serbia. The instrument used for the study was questionnaire ("student's organization questionnaire") conducted by the authors. The questionnaire is consisted of 12 items, based on the practical implications and theoretical framework of student organizations. Some questions were answered checking one or more answers, and some questions were based on Likert scale ( 1 - not at all true, 2 - mostly not true, 3 - not sure, 4 - mostly true, 5 - quite exactly), where respondends indicated their level of agreement with the given statement.

The questionnaire was anonymous, delivered via Google Forms, as a quick link, conducted in April and May 2017.

The structure of the whole sample with respect to sociodemographic variables (gender, age, occupation, professional experience/type of school, education) is presented as follows: 
Table 35: Gender of respondents

\begin{tabular}{lcccc} 
& \multicolumn{2}{c}{ Students } & \multicolumn{2}{c}{ Teachers } \\
Male & 66 & $38 \%$ & 19 & $20 \%$ \\
\hline Female & 108 & $62 \%$ & 76 & $80 \%$ \\
\hline & 174 & $100 \%$ & 95 & $100 \%$ \\
\hline
\end{tabular}

As shown in the Table 35 , in the survey participated $38 \%$ male students, and $62 \%$ female students. The age of student participants were in range 15 to 28 years old. Structure of students related to their current status is:

- $\quad 69,5 \%$ high school students,

- $\quad 20,1 \%$ university students,

- $\quad 10,4 \%$ already employed.

Analyzing data in the Table 36 . it is evident that $72,99 \%$ of respondents considered their participation in 'mini-company' will contribute increasing competencies for founding their own business.

Table 36: Contribution to student's competencies by participating in mini-companies in relation with current occupation of students

\begin{tabular}{|c|c|c|c|c|c|c|c|}
\hline \multirow{2}{*}{ S } & \multirow{2}{*}{$\begin{array}{l}\text { congly } \\
\text { sagree }\end{array}$} & \multicolumn{5}{|c|}{$\begin{array}{c}\text { Does Your participation in Mini-company contribute to your } \\
\text { competency for founding Your own business? }\end{array}$} & \\
\hline & & Disagree & $\begin{array}{l}\text { Neither } \\
\text { agree or } \\
\text { disagree }\end{array}$ & Agree & $\begin{array}{l}\text { Strongly } \\
\text { agree }\end{array}$ & Total & \\
\hline \multirow{4}{*}{$\begin{array}{l}\text { What is } \\
\text { Your cur- } \\
\text { rent oc- } \\
\text { cupation? }\end{array}$} & Unemployed & o & o & o & 1 & o & 1 \\
\hline & $\begin{array}{l}\text { Student-gra- } \\
\text { duated }\end{array}$ & 1 & 2 & 10 & 16 & 16 & 45 \\
\hline & $\begin{array}{l}\text { Student-cur- } \\
\text { rently }\end{array}$ & 2 & 5 & 25 & 45 & 44 & 121 \\
\hline & Employed & o & o & 2 & 4 & 1 & 7 \\
\hline \multicolumn{2}{|l|}{ Total } & 3 & 7 & 37 & 66 & 61 & 174 \\
\hline \multicolumn{2}{|l|}{$\%$} & 1,72 & 4,02 & 21,26 & 37,93 & 35,05 & 100 \\
\hline
\end{tabular}

Structure of teachers responsibility in the survey is shown as follows:

- $\quad 70 \%$ teaching vocational subjects

- $\quad 30 \%$ grammar school subjects (general education).

Question for the students: satisfaction with the program 'mini-companies'- it was suppose to estimate on the Likert scale. Results: 
- $\quad$ 93,11\% picked Agree and Strongly agree on the Likert scale which represents their high satisfaction with the program,

- $\quad 6,89 \%$ picked other items on the scale.

There is no significant difference between degree of satisfaction compared if respondents attend or not enterpreneurship course in the high school.

Table 37:Degree of satisfaction with the program and attenting subject entrepreneurship in school (cross tabulation)

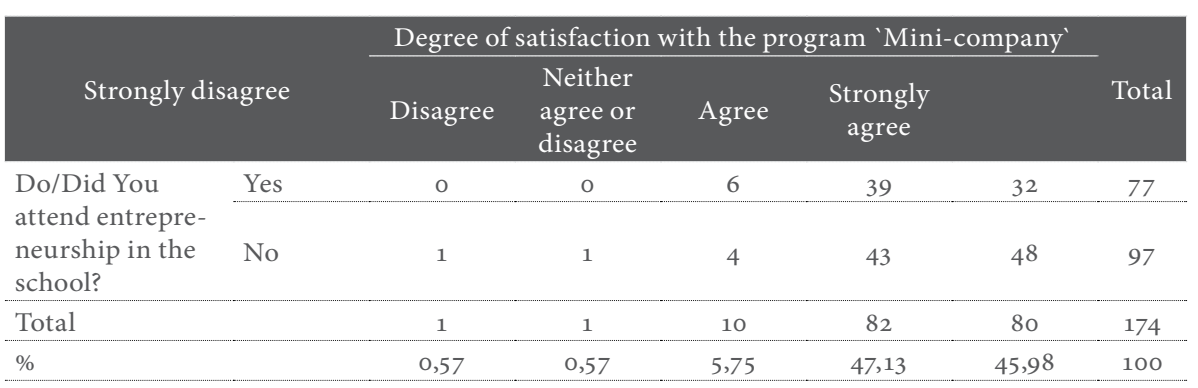

In terms of recommendation the program to other students, answers were:

$$
\begin{aligned}
& -\quad 98,85 \% \text { yes } \\
& \text { - } \quad 1,15 \% \text { no. }
\end{aligned}
$$

Table 38: Recommendation of the program and current occupation of students (cross tabulation)

\begin{tabular}{llccc} 
& & \multicolumn{2}{c}{$\begin{array}{c}\text { Would You recommend this pro- } \\
\text { gram to other students? }\end{array}$} & Total \\
\cline { 2 - 4 } & Unemployed & Yes & No & 1 \\
\hline \multirow{2}{*}{$\begin{array}{l}\text { What is Your } \\
\text { current occupation? }\end{array}$} & 1 & 0 & 45 \\
\cline { 2 - 4 } & Student -graduated & 45 & 2 & 121 \\
\hline Total & Student - currently & 119 & 0 & 7 \\
\hline Employed & 7 & 2 & 174 \\
\hline
\end{tabular}




\section{Results}

In our study we tried to assess different student and teacher statements related to work in 'mini-companies' in order to better understand their engagement in it, and study the positive effects of those engagements. There are certain observations there:

Students were asked to pick four of all proposed answers to declare why are they apply for program of 'mini-organizations'. Proposed answers were:

1. Curiosity

2. Techer's decision

3. Opportunity to earn something

4. Acquisition of new knowledge

5. Meeting new people and socializing

6. Absence from school

7. I estimate it as useful and profitable

8. Persuaded by friend

9. I can demonstrate my creativity and capacity for innovation

10. Personal development

11. I was idle

12. Other

Students are introduced to program -'mini-companies' mostly because of the following 5 reasons:

1. Acquisition of new knowledge $20,32 \%$

2. Meeting new people and socializing $17,31 \%$

3. Personal development $16,96 \%$

4. Curiosity $13,6 \%$

5. I estimate it as useful and profitable $12,72 \%$.

Results of teacher opinion have shown the similar grade of proposed categories.

1. Useful (for students) $32,44 \%$

2. Acquisition of new knowledge $27,86 \%$

3. Possibility of teacher's creative expression $14,88 \%$ 
Further, we investigate what knowledge and skills students have acquired during the program of 'mini-companies' according to their own opinion. This grade is shown in the Table 39.

Table 39: Students opinion about knowledge and skills improved during the program (the respondents were able to choose 4 answers in total)

\begin{tabular}{|c|c|c|c|}
\hline \multicolumn{4}{|c|}{ Students } \\
\hline \multicolumn{2}{|l|}{ Knowledge: } & \multicolumn{2}{|c|}{ Skills: } \\
\hline How the business world functions & $16,67 \%$ & Presentation skills & $13,82 \%$ \\
\hline $\begin{array}{l}\text { Creating a business plan \& a business } \\
\text { report }\end{array}$ & $14,88 \%$ & Teamwork & $12,54 \%$ \\
\hline Basics of how to run my own company & $13,84 \%$ & Confidence & $11,82 \%$ \\
\hline Time management + teamwork & $13,84 \%$ & Competitive spirit & $9,69 \%$ \\
\hline Marketing & $12,35 \%$ & Communication & $8,26 \%$ \\
\hline Decision making & $11,16 \%$ & Risk taking & $7,98 \%$ \\
\hline Basics of entrepreneurship & $10,42 \%$ & Creativity development & $7,55 \%$ \\
\hline Business correspondence & $2,68 \%$ & Setting goals & $7,55 \%$ \\
\hline Knowledge in English & $2,23 \%$ & Negotiation skills & $7,41 \%$ \\
\hline IT competencies & $1,64 \%$ & How to fight for my idea & $6,27 \%$ \\
\hline \multirow[t]{3}{*}{ No added value for me } & $0,30 \%$ & Organizing & $4,27 \%$ \\
\hline & & Dealing with conflict & $2,85 \%$ \\
\hline & & No added value for me & $0,0 \%$ \\
\hline
\end{tabular}

Equally important is opinion of teachers regarding accomplished skills and knowledge of their students during the attendance course of 'mini-companies'. It is shown in the Table 40:

Table 40: Teachers opinion of knowledge and skills students improved during the program (the respondents were able to choose 4 answers in total)

\begin{tabular}{lclc}
\multicolumn{1}{c}{ Teachers } & \\
\hline \multicolumn{1}{c}{ Knowledge: } & & & Skills: \\
\hline How the business world functions & $19,79 \%$ & Teamwork & $18,90 \%$ \\
\hline $\begin{array}{l}\text { Creating a business plan \& a business } \\
\text { report }\end{array}$ & $16,84 \%$ & Presentation skills & $17,59 \%$ \\
\hline $\begin{array}{l}\text { Basics of how to run my own company } \\
\text { Time management \& teamwork }\end{array}$ & $14,97 \%$ & Confidence & $14,44 \%$ \\
\hline
\end{tabular}




\begin{tabular}{lcll}
\hline Basics of entrepreneurship & $11,23 \%$ & Competitive spirit & $10,76 \%$ \\
\hline Decision making & $10,70 \%$ & How to fight for their idea & $6,82 \%$ \\
\hline Marketing & $9,36 \%$ & Communication & $6,04 \%$ \\
\hline IT competencies & $2,41 \%$ & Setting goals & $4,46 \%$ \\
\hline Knowledge in English & $1,60 \%$ & Negotiation skills & $2,62 \%$ \\
\hline Business correspondence & $0,80 \%$ & Risk taking & $2,62 \%$ \\
\hline No added value for students & $0,27 \%$ & Organizing & $1,57 \%$ \\
\hline & & Dealing with conflict & $0,79 \%$ \\
\hline
\end{tabular}

In addition to the previous, we analyze categories labeled 'other' in the questionnaire which was set up as a free form. Teachers got a chance to give descriptive answers on what the positive experiences working with students in 'mini-companies' were. Most of their answer can be summarized in the few following items:

1. Two - way communication with students.

2. Excellent feedback for the future teaching lessons.

3. Clear link between the business and economy.

4. Problem-solving techniques which are not related to education institutions.

5. The removal of barriers between students and teachers, encouraging students' motivation and innovation.

6. Personal development of students and their teachers.

7. Socializing and meeting interesting people.

8. Creative work with students.

Besides that, the most important visible result was upgraded knowledge of the students and positive attitude toward their future occupation. Teachers argue that students who attended the program of 'mini-companies' turn out to be individuals who successfully respond to all the opportunities and challenges of the business life. All this is due to the facts that they developed or promoted key skills important for business managing, gained self-confidence, took the initiative, learnt how to make decisions, mastered problem solving, coped with networking, and identified opportunities and personal effectiveness. 
It represents one step closer to sustainable careers of students as future employees in real corporations.

\section{Discussion and recommendation for the future research}

The analysis of the results leads to the conclusion that the main assumption "participation in the mini-companies will lead to increase in the knowldge of students and development of skills and competencies" is proven. Hence, results have shown a direct and clear connection between leading mini-companies and the major development of business-related student knowledge and soft skills. There is also an agreement between teacher and student opinion concerning the positive effects of participation in the mini-companies program. The students considered they've upgraded and improved their skills and knowledge, concurring with teachers' attitude that program has been successful and useful for students. Another positive side of participation in mini-companies could be motivating teachers with higher potential to utilize their professional and business knowledge. All the aforementioned is in accordance with the prior studies (Kisic Petkovic 2019; Lackeus 2005; Williamson et.al. 2013), which argue that mini-companies provide excellent foundation for continuous education, promoting business knowledge, encouragement to evolve skills and prepare students for future challenges in their academic, private and business life.

However, there are some limitations in our research. Research instruments need to be expanded for future researches in order to get a clear picture of all the aspects of participation in 'mini-organization' program: it is necessary to make a distinction between the opinions of current students and students who finished high school, broader opinion of teachers with regards to their experience in the real business situation, following further steps in the student's career after the finished program and high school, etc. Consequently, we propose additional research in the forthcoming year, with comprehensive instrument and more extended statistical analysis to encompass all types of schools, more students and their mentors, and broad spectrum of skills and competencies of students. Furthermore, it is suggested to consider how mini-companies can become sustainable, with regards to the sustainable venture creation approach (Lackeus, 2013). 


\section{Literature}

Kisic, S. Petkovic, 2019. Human Capital During the Fourth Industrial Revolution - from the lifelong learning up to lifelong Employability", Proceedings of the $14^{\text {th }}$ International Symposium on Corporate Governance "Sustainable Development of Small Economics in the Industrial Revolution 4.0 - Chances and Limitations", Teslic, 22. - 24. May 2019., p: 121 - 149, UDK 37.014:36776] 339.923)

Kisic S., 2015, Rezultati istrazivanja efekta programa 'Ucenicka kompanija" u srednjim skolama u Srbiji, Godisnja konferencija nastavnika Dostignuca mladih u Srbiji, 2019

Lackéus, Martin, Entrepreneurship in Education: What, Why, When, How, OECD, 2015.

Lackeus, Martin, Developing entrepreneurial competencies: An action-based approach and classification in entrepreneurial education, Chalmers University of Technology Gothenburg, Sweden, 2013.

Limerick, David C., Larry F. Moore, A winning Relationship: managing the student-company learning interface, Journal of management education, 1991.

Neck, Heidi M., Greene Patricia G., Brush Candida G., Teaching entrepreneurship: A Practice-Based Approach, Edward Elgar Publishing Cheltenham $\mathrm{UK}, 2014$.

Porter, Lyman W., McKibbin Lawrence E., Management education and development: Drift of thrust ino the $21^{\text {st }}$ century? New York: McGraw-Hill, 1988.

Cousins, Roland B., Thorn Ron G., Benitz Linds E., The junior achievement company as a living case, Journal of management education, 1995.

Williamson, Naomi, Beadle Shane, Charalambous Stephanie, Enterprise education impact in higher education and further education:Final report, Department for business, innovation and skills, ICF GHK International Company, 2013.

\section{Websites}

Entreprenurial Learning Toolkit for Teachers (https://ec.europa.eu/jrc/en/publication); (May 25, 2019).

Kisic, S. Petkovic, http://ses.org.rs/upload/Ekonomika\%2opreduzeca\%201-22019.pdf ( July 30, 2019).

The Quality Assurance Agency for Higher Education (QAA) guidance on enterprise and entrepreneurship provision7 draws the distinction set out in 
the box below. See http://www.qaa.ac.uk/Publications/InformationAndGuidance/Documents/EE_Draft_Guidance.pdf ; OECD, (July 8, 2020)

DG Enterprise and Industry website, http://ec.europa.eu/enterprise/policies/ sme/promoting-entrepreneurship/education-trainingentrepreneurship/ index_en.htm (July 7, 2020)

\section{Sources}

The Quality Assurance Agency for Higher Education (QAA) guidance on enterprise and entrepreneurship provision draws the distinction set out in the box below. See http://www.qaa.ac.uk/Publications/InformationAndGuidance/Documents/EE_Draft_Guidance.pdf ; OECD (2010) Ministerial report on the OECD innovation strategy; and OECD (2009) Evaluation of programmes concerning education for entrepreneurship: Report of the OECD Working Party on SMEs and Entrepreneurship; DG Enterprise and Industry website, http://ec.europa.eu/enterprise/policies/sme/ promoting-entrepreneurship/education-trainingentrepreneurship/index_en.htm

(2010) Ministerial report on the OECD innovation strategy; and OECD (2009) Evaluation of programmes concerning education for entrepreneurship: Report of the OECD Working Party on SMEs and Entrepreneurship 